\title{
School Management Competencies: Perceptions and Self-Efficacy Beliefs of School Principals
}

\author{
Yamina Bouchamma' ${ }^{1}$, Marc Basque ${ }^{2}$, Caroline Marcotte ${ }^{1}$ \\ ${ }^{1}$ Department Foundations and Practices in Education, Laval University, Quebec, Canada \\ ${ }^{2}$ Department of Kinesiology and Recreation, Moncton University, New Brunswick, Canada \\ Email: yamina.bouchamma@fse.ulaval.ca
}

Received 19 March 2014; revised 19 April 2014; accepted 26 April 2014

Copyright (C) 2014 by authors and Scientific Research Publishing Inc.

This work is licensed under the Creative Commons Attribution International License (CC BY). http://creativecommons.org/licenses/by/4.0/

c) (i) Open Access

\begin{abstract}
In several contexts, reform in the training and nomination of future school principals was based on competency profiles. In Québec, it was not until 2008 that its Ministry of Education established a profile of competencies specifically for school principals. This study proposed a questionnaire on the perceptions and self-efficacy beliefs of school principals with regard to these competencies and their associated factors. Respondents gave greater weight to the management of education services, followed by human resources, educational environment, and finally, administration. A significant difference was observed between administrative management and the teaching level and school size. The principals whose professional development activities consisted of conventions and seminars also felt a greater sense of personal efficacy on this factor compared to the principals whose professional development was done through mentoring.
\end{abstract}

\section{Keywords}

School Management Competencies, School Management Competencies, Self-Efficacy Beliefs, School Principals

\section{The Context of Reform}

Until 1980, no nation possessed a clearly defined national policy on the training standards for school principals. It was only in the early 21st century that several countries became aware of the importance of specific training for school leaders (Bush, Kiggundu, \& Moorosi, 2011; Bush, 2008). Indeed, the many societal transformations have generated significant changes in the education system and ultimately, complex challenges for school prin- 
cipals (Bush, 2008; Warfield, 2009; Levine, 2005). The building superintendent of yore must now possess multiple forms of expertise, such as academic content, data analysis, public relations, and change management (Darling-Hammond et al., 2007; Huber, 2008; Levine, 2005; Perez et al., 2011).

Research has shown that school principals do in fact play a pivotal role in improving school and classroom conditions and in teacher supervision, not to mention student learning (Davis et al., 2005; Hallinger \& Heck, 1998; Leithwood et al., 2004; Louis et al., 2010). This effect, which is second only to in-class teaching (Leithwood et al., 2004), occurs through the influence they have on their teachers' level of commitment and motivation, work conditions, and distribution of power (Leithwood et al., 2006), or through their organisation of the school's culture (Wahlstrom \& Seashore, 2008; Robinson et al., 2008). Effective principals also enrich teacher performance (Lee, Dedrick, \& Smith, 1991; Lee, Buck, \& Midgley, 1992; Rosenholtz, 1989) as well as the latter's sense of efficacy in their practices (Smylie, 1988; Hipp, 1996; Hipp \& Bredeson, 1995). This observation has led to an acknowledgement of their profession as one requiring specialised capabilities that warrant specific training and preparation beyond innate qualities (Bush, 2008, 2010; Avolio, 2005; Lumby et al., 2008). Thus training programs for young principals and professional development for in-service school leaders must expand their expertise so as to better respond to the growing demands (Ravitch, 2010).

It goes without saying that the training requirements for the position of school principal vary depending on the context. In the United States, for example, a teacher becomes eligible for promotion to the position of principal when they have completed a Masters in educational administration (Tucker \& Codding, 2002), while in the United Kingdom, teachers must climb the ranks to become senior faculty, or "deputy head", and must assist the principal during a minimum of five years before being allowed to apply for the position of headmaster (Weindling \& Dimmock, 2006).

In Québec, having a degree in school management only became a job requirement for the position of principal in 2001. In the wake of this reform, Québec's Ministère de l'éducation, du loisirs et des sports (MELS) enacted new policy with its profile of professional competencies for school principals. This study centered on the perceptions of school principals and their self-efficacy beliefs with regard to these required qualifications, and asked the following research questions: How did school principals view the competencies expressed in the MELS profile on training in the administration of educational institutions (MELS, 2008)? What were their self-efficacy beliefs regarding these competencies and which factors were associated with these perceptions?

\section{Literature Review}

Several arguments support the idea of specific training for school leaders and the importance of investing in their formal development so as to improve the quality of school leadership. To meet the demands of a constantly evolving society, schools must have well-qualified principals, as the latter have a definite impact on student performance (Hallinger, 2003; Leithwood et al., 2006). In this sense, "professionalising” the principal's role and recognising the differences between their role and that of their teachers calls for separate and specialised training and preparation (Van der Westhuizen \& Van Vuuren, 2007; Bouchamma, 2013).

Many authors have noted a serious lack of knowledge in the field as regards the professional development of school principals (Nicholson et al., 2005; Salazar, 2007; Rodriguez-Campos et al., 2005), the evaluation of these professional growth activities (Howley et al., 2002; Leithwood \& Levin, 2008; Nicholson et al., 2005), the type of professional upgrading principals engage in (Nicholson et al., 2005), and the effect professional development may have on student achievement (Howley et al., 2002; Leithwood \& Levin, 2008; Nicholson et al., 2005; Salazar, 2007).

\subsection{Training for Principals and Continuing Professional Development}

Two main options exist in the training of school principals, namely, the initial identification and training of potential candidates prior to their nomination and the continuing professional development of in-service principals (Daresh \& Male, 2000). Regardless of the choice, the development of school principals—not to mention the recruitment and retention —-must be a priority in each and every education system (Chapman, 2005).

Despite the relevance, specific training remains inaccessible in many contexts. In some countries, school principals often begin their professional careers as teachers, progressing toward the directorial position through experience (Bush et al., 2011; Mestry \& Singh, 2007), while in others, the training of principals is increasingly accepted as a means to improve student achievement. Such is the case in some South African urban area schools 
that have succeeded in implementing professional development programmes for school principals who seek to enrich their skills and practices (Mestry \& Schmidt, 2010).

In the context of Africa, school principals are often promoted based on their success as teachers, although many point out that success in teaching does not automatically mean success as a principal (Bush \& Oduro, 2006; Van der Westhuizen et al., 2004) and that principals with no basic management skills are unable to survive the many changes (Kitavi \& Van der Westhuizen, 1997).

\subsection{The Benefits of Training}

Some studies have qualified leadership development as a "strategic necessity" (Brundrett, Fitzgerald, \& Sommefeldt, 2006). Effective training programmes generate numerous positive benefits on the leadership qualities of school principals in the sense that they reduce the shock of the passage from the role of teacher to that of principal (Daresh \& Male, 2000). Moreover, when these initiatives are not successful, the principals tend not only to lose interest in future professional development training but also become reticent in welcoming change (Knight, 2007).

In a study conducted in four American states on the professional development of school principals, professional development activities were viewed as being essential for them to respond to the demands of student achievement and their professional practice (Nicholson et al., 2005).

Many education systems emphasise the need to focus on the principals' professional development in order to introduce effective management and elevate the level of leadership of school principals (Mathibe, 2007; Salazar, 2007). Because of the many challenges facing principals in many low-performing urban schools in America, this situation is even more critical (Houle, 2006). Studies have shown the importance of addressing the practice in the training programmes for future principals, making these development activities more easily applicable to the real-life day-to-day situations, connecting theory and practice, and giving school principals enough time to reflect and to exercise their practice (Dinham, Anderson, Caldwell, \& Weldon, 2011).

In Québec, the massive exodus of retired principals in the early 2000s raised a serious concern regarding accelerated replacement and resulted in research related to the difficulties caused by this precipitated action. As a result, the movement toward administrative decentralisation and the resulting increased responsibilities for the schools have led to a complexification of the principal's responsibilities. Thus the law governing the working conditions of school commission leaders called for a Masters degree in management, thereby emphasising the importance of continuing education for school principals.

In response, two studies were conducted which led to the elaboration of government policy entitled La formation à la gestion d'un établissement d'enseignement orientations et les compétences professionnelles in which Québec's Ministry of Education (2008) profiled a list of required professional qualifications for school principals: the first study centered on the support and supervision practices of new principals (MELS, 2006), while the second focused on professional integration (Fortin, 2006). With the help of these two works, the coordination committee was able to construct a common reference list of competencies. In the subsequent document, the MELS elaborated the orientations and professional capabilities expected of future principals of training centres and schools of all levels, from pre-school to secondary.

This official document thus presented a reference guide to the ten competencies defining the school management training programme. These interdependent skills were divided into four skills management groups: education services, educational environment, human resources, and administration.

\section{Conceptual Framework}

Two key concepts defined our conceptual framework: professional development and self-efficacy beliefs.

\subsection{Professional Development}

The concept of professional development is defined as an intensive, comprehensive and supported initiative centered on improving the effectiveness of both teachers and principals to ultimately have a positive impact on student outcomes (Hirsh, 2009). It involves processes and activities through which educators acquire professional knowledge, skills (National Staff Development Council, 2000), and attitudes to enrich student learning (Guskey, 2000). 


\subsection{Self-Efficacy Beliefs}

Formerly referred to as the sociocognitive theory (Bandura, 1977, 1986), the theory of self-efficacy is a social learning theory. It is the subjective belief an individual has in their capacity to successfully perform a given action. This theory not only represents one of the most determinant psychological mechanisms of human behaviour (Bandura, 1989) but is also one of the most important concepts in the family of motivational theories (Landy, 1991; Locke, 1991; Gorrell, 1990; Schunk, 1995). Based on objective and subjective elements, the selfefficacy belief represents the conviction an individual develops in terms of their capacity to deal with what is required in a given situation. As a situational variable (Bandura, 1986, 1996), its strength and scope vary depending on the context and various spheres of life of the individual.

Self-efficacy is developed through various mechanisms: cognitive (notably by determining the objectives), motivational (i.e. by adopting self-regulatory practices), and affective (by controlling anxiety and promoting avoidance behaviours). Many studies have shown possible connections between self-efficacy, favoured behaviours, and persistence when dealing with challenges (Schunk, 1996). According to some authors, the Self-efficacy may be developed through adequate practices and appropriate interventions (Bandura, 1997; Betz \& Luzzo, 1996; Maddux \& Lewis, 1995), and concrete actions to improve the Self-efficacy may be introduced to enrich an individual's performance.

\section{Methods}

\subsection{Sample}

In total, 49 school principals and vice-principals responded to our questionnaire: $53.1 \%$ were women, $89.8 \%$ were tenured, $85.7 \%$ were principals; $69.4 \%$ were employed in primary schools, $26.5 \%$ in secondary schools, and $4.1 \%$ in adult education. Among them, $54 \%$ possessed a degree in school administration, while $45.5 \%$ were studying to obtain this certification. On average, the respondents possessed 12.95 years of teaching experience, with 7.8 years as principal. Average age was 43.3 years old. They were responsible for an average of 24.4 teachers and 397.6 students in schools with a socioeconomic status index (SES) of 5.9 on a scale of 10 (10 being the most disadvantaged).

\subsection{Data Collection}

The Questionnaire School Management Competencies: Perceptions and Self-Efficacy of School Principals was devised to present our research questions to the participating principals and was divided into three sections: 1) their personal characteristics as well as the sociodemographic and socioprofessional characteristics of the school; 2) the importance they gave to the 10 competencies of school principals (MELS, 2008); and 3) their self-efficacy belief with regard to these competencies. The principals were asked to respond to the last two sections by means of a Likert-type scale consisting of 6 items ranging respectively from Not at all important to Extremely important and from Totally disagree to Totally agree.

\section{Results}

\subsection{Degree of Importance Given to the 10 Competencies}

Bouchamma et al. based on the four school management skills (education services, educational environment, human resources, and administrative resources), our analysis (see Table 1) shows that the principals felt the strongest regarding the management of Education Services $(M=5.66)$, followed by Human Resources $(M=$ 5.39), Educational Environment ( $M=5.15)$, and Administration $(M=5.03)$.

\subsection{Self-Efficacy Beliefs Regarding the 10 Competencies}

Concerning their self-efficacy (see Table 2) beliefs toward the 10 school management competencies, these perceptions were stronger with regard to Education Services $(M=5.60)$, followed by Educational Environment (M = 4.84), Human Resources $(M=4.69)$, and finally, Administration $(M=4.55)$.

\subsection{Importance Given to Administration by Teaching Level and School Size}

Our analysis of the degree of importance given to each of the four management competencies (see Table 3) 
Table 1. Degree of importance given to the 10 competencies.

\begin{tabular}{|c|c|c|}
\hline Management competency & M & ET \\
\hline Education services & 5.66 & 0.98 \\
\hline 1) Organise the school to focus on the students' academic needs. & 5.65 & 1.03 \\
\hline 2) Support the development of instructional practices adapted to the students' needs. & 5.67 & 0.99 \\
\hline Educational environment & 5.15 & 0.95 \\
\hline 3) Assist the school council as mandated by law. & 5.02 & 1.15 \\
\hline 4) Head the development of a school initiative and the implementation of a results-oriented academic achievement plan. & 5.29 & 1.04 \\
\hline 5) Foster the development of collaborations and partnerships centered on student achievement. & 5.14 & 1.02 \\
\hline Human resources & 5.39 & 0.78 \\
\hline 6) Ensure effective action in my practice and in that of my staff members. & 5.49 & 0.77 \\
\hline 7) Ensure effective action by each work group. & 5.33 & 0.88 \\
\hline 8) Continue to develop my skills and those of my staff members. & 5.37 & 0.95 \\
\hline Administration & 5.03 & 0.97 \\
\hline 9) Effectively and efficiently manage the school's financial resources. & 5.12 & 1.09 \\
\hline 10) Effectively and efficiently manage the school's material resources. & 4.94 & 1.03 \\
\hline
\end{tabular}

$\mathrm{N}=49$.

Table 2. Self-efficacy belief regarding the 10 competencies.

\begin{tabular}{|c|c|c|}
\hline Management competency & $M$ & $E T$ \\
\hline Education services & 5.9 & 0.95 \\
\hline 1) Organise the school to focus on the students' academic needs. & 5.14 & 0.88 \\
\hline 2) Support the development of instructional practices adapted to the students' needs. & 5.04 & 1.14 \\
\hline Educational environment & 4.84 & 0.86 \\
\hline 3) Assist the school council as mandated by law. & 4.94 & 0.99 \\
\hline 4) Head the development of a school initiative and the implementation of a results-oriented academic achievement plan. & 4.96 & 1.11 \\
\hline 5) Foster the development of collaborations and partnerships centered on student achievement. & 4.61 & 0.93 \\
\hline Human resources & 4.69 & 0.89 \\
\hline 6) Ensure effective action in my practice and in that of my staff members. & 4.82 & 0.95 \\
\hline 7) Ensure effective action by each work group. & 4.63 & 1.05 \\
\hline 8) Continue to develop my skills and those of my staff members. & 4.63 & 1.35 \\
\hline Administration & 4.55 & 1.14 \\
\hline 9) Effectively and efficiently manage the school's financial resources. & 4.53 & 1.08 \\
\hline 10) Effectively and efficiently manage the school's material resources. & 4.57 & 0.95 \\
\hline
\end{tabular}

$\mathrm{N}=49$. 
Table 3. Degree of importance given to administration by teaching level and school size.

\begin{tabular}{cccc}
\hline Variable & $M(S D)$ & $F$ & $D f$ \\
Teaching level & $4.74(0.96)$ & & \\
Primary & $5.73(0.60)$ & $6.349^{* *}$ & \\
Secondary & & & \\
Adult education & $5.50(0.71)$ & & \\
School size & & \\
Small & $4.53(1.04)$ & $3.537^{*}$ \\
Medium & $5.22(1.05)$ & \\
Large & $5.33(0.56)$ &
\end{tabular}

revealed a significant difference between Administration management, the teaching level, and the size of the school.

Teaching level (primary, secondary, adult) sparked a notable difference between the schools. The secondary school principals $(\mathrm{M}=5.73$; ET $=0.60)$ placed greater importance on this competency compared to their peers in primary schools $(\mathrm{M}=4.74$; $\mathrm{ET}=0.96),[\mathrm{F}(2.46)=6.349, p<0.01]$. Our results also indicate that the respondents from large schools felt stronger with regard to Administration $(\mathrm{M}=5.33$; ET = 0.56) than did the respondents from small schools $(\mathrm{M}=4.53$; $\mathrm{ET}=1.04)$, $[\mathrm{F}(2,46)=3.537, p<0.05]$.

\section{Self-Efficacy Beliefs Regarding Professional Development}

Only one relationship was found to be significant between self-efficacy belief and type of professional development (in the form of conventions/seminars or mentoring) (see Table 4). In The respondents whose professional development activities were conventions and seminars $(\mathrm{M}=5.41$; ET $=0.71)$ experienced a greater feeling of self-efficacy with regard to Competency no. 4, Head the development of a school initiative and the implementation of a results-oriented academic achievement plan, compared to the respondents whose professional development was gained through mentoring $(\mathrm{M}=4.33$; $\mathrm{ET}=1.23),[\mathrm{F}(2.39)=5.100, p<0.05]$.

\section{Discussion}

The aim of this study was to identify the perceptions and self-efficacy beliefs of school principals with regard to the competencies of principals and the associated factors.

Our results show that the participating principals placed greater importance on the management of Education Services, followed by Human Resources, Educational Environment, and Administration. This finding supports the changing role of the school principal depending on the context. This role takes precedence over that related to administrative functions by privileging pedagogy and student achievement and thus reflects the preoccupation of education systems to improve student outcomes. School principals in Québec who are increasingly concerned with improving perseverance and achievement in school must develop a results-oriented management model (MELS, 2004, 2009). Based on measurable results, this management approach is defined by taking into account the services that are required. To reach the proposed objectives, three principles are evoked, namely, transparency, accountability, and flexibility (Secrétariat du Conseil du Trésor du Québec, 2002). Our results varied, however, on certain school characteristics. A significant difference was noted between the primary and secondary characteristics in terms of the importance the respondents gave to Competency no. 9 effectively and efficiently manage the financial resources, and Competency no. 10 effectively and efficiently manage the material resources, as the secondary school principals showed greater interest in administrative management than did their peers from the primary sector. Because secondary schools are generally larger and are responsible for larger budgets, it is suggested that the principals of these establishments devote a greater portion of their time to administrating. 
Table 4. Self-efficacy belief regarding the type of professional development.

\begin{tabular}{|c|c|c|c|}
\hline & $M(S D)$ & $F$ & $D f$ \\
\hline Conventions and seminars & $5.41(0.71)$ & \multirow[b]{2}{*}{$5.100^{*}$} & \multirow[b]{2}{*}{2.46} \\
\hline Mentoring & $4.33(1.23)$ & & \\
\hline
\end{tabular}

Note. ${ }^{*}=p \leq 0.05 .^{* *}=p \leq 0.01$.

Overall, the respondents' self-efficacy beliefs did not differ because of the type of professional development process employed, although differences were found for two competencies related to the management of the educational environment. For Competency no. 4 head the development of a school initiative and the implementation of a results-oriented academic achievement plan, the respondents who took part in conventions or seminars for their professional development felt more competent on this aspect compared to the respondents whose professional development involved only mentoring. The principals' responses were also similar for Competency no. 5 Foster the development of collaborations and partnerships centered on student achievement, as principals who participated in conventions and seminars gave greater weight to this competency, compared to their colleagues whose professional development consisted of mentoring.

Only a few studies explore the type of professional development activities chosen by school principals (Nicholson et al., 2005; Salazar, 2007; Rodriguez-Campos et al., 2005) and there is even less research on how this professional development is assessed (Howley et al., 2002; Leithwood \& Levin, 2008; Nicholson et al., 2005). However, other research orientations continue to develop, such as the nature and goals of educational leadership, mentoring, and professional development coaching programmes (Huber, 2008), to name a few. What must be retained from our study is the positive impact of training seminars, as it is through this type of training activity that new ideas in school management are introduced, that interactions between participants are encouraged, and that points of view are put into perspective through discussion.

While this study was conducted with a relatively small sample, future research should target a larger sample and should not only be limited to generalization but also allow further analyzes that take into account the contextual characteristics of schools where these school leaders work (Schools in disadvantaged areas, rural/urban schools.

\section{Conclusion}

In conclusion, a number of lines of action may be pursued as a result of this study. Future research should ideally include, among others, qualitative studies by means of interviews and direct observation to learn more regarding the day-to-day work involved and the competencies required for effective school management.

\section{References}

Avolio, B. J. (2005). Leadership Development in Balance: Made/born. Mahwah, NJ: Lawrence Erlbaum.

Bandura, A. (1977). Self-Efficacy: Toward a Unifying Theory of Behavioural Change. Psychological Review, 84, $191-215$. http://dx.doi.org/10.1037/0033-295X.84.2.191

Bandura, A. (1986). Social Foundations of Thought and Action. Englewood Cliffs, NJ: Prentice Hall.

Bandura, A. (1989). Social Cognitive Theory. In R. Vasta (Ed.), Annals of Child Development. Six Theories of Child Development (Vol. 6, pp. 1-60). Greenwich, CT: JAI Press.

Bandura, A. (1996). Ontological and Epistemological Terrains Revisited. Journal of Behavior Therapy and Experimental Psychiatry, 27, 323-345. http://dx.doi.org/10.1016/S0005-7916(96)00049-3

Bandura, A. (1997). Self-Efficacy: The Exercise of Control. New York: Freeman.

Betz, N. E., \& Luzzo, D. A. (1996). Career Assessment and the Career Decision-Making Self-Efficacy Scale. Journal of Career Assessment, 4, 413-428. http://dx.doi.org/10.1177/106907279600400405

Brundrett, M., Fitzgerald, T., \& Sommefeldt, D. (2006). The Creation of National Programmes of School Leadership Development in England and New Zealand: A Comparative Study. International Studies in Educational Administration, 34, 89105. 
Bush, T. (2008). Leadership and Management Development in Education. London: Sage.

Bush, T. (2010). Theories of Educational Leadership and Management (4th ed.). London: SAGE.

Bush, T., Kiggundu, E., \& Moorosi, P. (2011). Preparing New Principals in South Africa: The ACE School Leadership Programme. South African Journal of Education, 31, 31-43.

Bush, T., \& Oduro, G. (2006). New Principals in Africa: Preparation, Induction and Practice. Journal of Educational Administration, 44, 359-375. http://dx.doi.org/10.1108/09578230610676587

Chapman, J. D. (2005). Recruitment, Retention, and Development of School Principals. Paris: UNESCO International Institute for Educational Planning and the International Academy of Education.

Daresh, J., \& Male, T. (2000). Crossing the Boundary into Leadership: Experiences of Newly Appointed British Headteachers and American Principals. Educational Management and Administration, 28, 89-101. http://dx.doi.org/10.1177/0263211X000281013

Darling-Hammond, L., Lapointe, M., Meyerson, D., \& Orr, M. T. (2007). Preparing School Leaders for a Changing World: Lessons from Exemplary Leadership Development Programs. Stanford, CA: Stanford University Educational Leadership Institute.

Davis, S., Darling-Hammond, L., LaPointe, M., \& Meyerson, D. (2005). School Leadership Study: Developing Successful Principals. Stanford, CA: Stanford University Educational Leadership Institute.

Dinham, S., Anderson, M., Caldwell, B., \& Weldon, P. (2011). Breakthroughs in School Leadership Development in Australia. School Leadership and Management, 31, 139-154. http://dx.doi.org/10.1080/13632434.2011.560602

Fortin, R. (2006). L’insertion professionnelle des nouvelles directions d'établissement d'enseignement.

Gorrell, J. (1990). Some Contributions of Self-Efficacy Research to Self-Concept Theory. Journal of Research and Development in Education, 23, 73-81.

Guskey, T. R. (2000). Evaluating Professional Development. Thousand Oaks, CA: Corwin Press.

Hallinger, P. (2003). Leading Educational Change: Reflections on the Practice of Instructional and Transformational Leadership. Cambridge Journal of Education, 33, 329-352. http://dx.doi.org/10.1080/0305764032000122005

Hallinger, P., \& Heck, R. H. (1998). Exploring the Principal's Contribution to School Effectiveness: 1980-1995. School Effectiveness and School Improvement: An International Journal of Research, Policy and Practice, 9, 157-191. http://dx.doi.org/10.1080/0924345980090203

Hipp, K. (1996). Teacher Efficacy: Influence of Principal Leadership Behavior. Paper Presented at the Annual Meeting of the American Educational Research Association, New York.

Hipp, K., \& Bredeson, P. (1995). Exploring Connections between Teacher Efficacy and Principals’ Leadership Behaviors. Journal of School Leadership, 5, 136-150.

Hirsh, S. (2009). A New Definition. Journal of Staff Development, 30, 10-16.

Houle, J. (2006). Professional Development for Urban Principals in Underperforming Schools. Education and Urban Society, 38, 142-159. http://dx.doi.org/10.1177/0013124505282611

Howley, A., Chadwick, K., \& Howley, C. (2002). Networking for the Nuts and Bolts: The Ironies of Professional Development for Rural Principals. Journal of Research in Rural Education, 17, 171-187.

Huber, S. (2008). School Development and School Leadership Development: New Learning Opportunities for School Leaders and Their Schools. In J. Lumby, G. Crow, \& P. Pashiardis (Eds.), International Handbook on the Preparation and Development of School Leaders (pp. 163-175). New York: Taylor and Francis.

Kitavi, M., \& Van der Westhuizen, P. C. (1997). Problems Facing Beginning Principals in Developing Countries: A Study of Beginning Principals in Kenya. International Journal of Educational Development, 17, 251-263.

http://dx.doi.org/10.1016/S0738-0593(96)00050-8

Knight, J. (2007). Instructional Coaching: A Partnership Approach to Improving Instruction. Thousand Oaks, CA: Corwin Press.

Landy, M. (1991). Socialist Education Today: Pessimism or Optimism of the Intellect? Rethinking Marxism, 4, 9-23.

Lee, M., Buck, R., \& Midgley, C. (1992). The Organizational Context of Personal Teaching Efficacy. Paper Presented at the Annual Meeting of the American Educational Research Association, San Francisco, CA.

Lee, V. E., Dedrick, R. F., \& Smith, J. B. (1991). The Effect of the Social Organization of Schools on Teachers' Efficacy and Satisfaction. Sociology of Education, 64, 190-208. http://dx.doi.org/10.2307/2112851

Leithwood, K., Day, C., Sammons, P., Harris, A., \& Hopkins, D. (2006). Seven Strong Claims about Successful School Leadership. Nottingham: NCSL/DfES Publications.

Leithwood, K., \& Levin, B. (2008). Understanding and Assessing the Impact of Leadership Development. In J. Lumby, G. 
Crow, \& P. Pashiardis (Eds.), International Handbook on the Preparation and Development of School Leaders (pp. 280302). New York: Taylor and Francis.

Leithwood, K., Louis, K. S., Anderson, S., \& Wahlstrom, K. (2004). How Leadership Influences Student Learning: Review of Research. New York: Wallace Foundation.

Levine, A. (2005). Educating School Leaders. The Education Schools Project. http://www.edschools.org/pdf/Final313.pdf

Locke, E. A. (1991). The Motivation Sequence, the Motivation Hub, and the Motivation Core. Organizational Behavior and Human Decision Processes, 50, 288-299. http://dx.doi.org/10.1016/0749-5978(91)90023-M

Louis, K. S., Leithwood, K., Wahlstrom, K., \& Anderson, S. (2010). Investigating the Links to Improved Student Learning: Final Report of Research Findings. New York: Wallace Foundation.

Lumby, J., Crow, G., \& Pashiardis, P. (2008) International Handbook on the Preparation and Development of School Leaders. New York: Taylor and Francis.

Mathibe, I. (2007). The Professional Development of School Principals. South African Journal of Education, 27, 523-540.

Mestry, R., \& Schmidt, M. (2010). Portfolio Assessment as a Tool for Promoting Professional Development of School Principals: A South African Perspective. Education and Urban Society, 42, 352-373. http://dx.doi.org/10.1177/0013124509357694

Mestry, R., \& Singh, P. (2007). Continuing Professional Development for Principals: A South African Perspective. South African Journal of Education, 27, 477-490.

Ministère de l'Éducation, du Loisirs et des Sports (MELS) (2004). Information et reddition de comptes des établissements scolaires aux parents et à la communauté. Québec, CA: Gouvernement du Québec.

Ministère de l'Éducation, du Loisirs et des Sports (MELS) (2006). Étude des pratiques de soutien et d'accompagnement des nouvelles directions d'établissement. Québec, CA: Gouvernement du Québec.

Ministère de l'Éducation, du Loisirs et des Sports (MELS) (2008). La formation à la gestion d'un établissement d'enseignement.

http://www.mels.gouv.qc.ca/sections/publications/publications/epeps/form_titul_pers_scolaire/07-00881.pdf

Ministère de l'Éducation, du Loisirs et des Sports (MELS) (2009). La convention de partenariat, outil d'un nouveau mode de gouvernance: Guide d'implantation. Québec, CA: Gouvernement du Québec.

Nicholson, B., Harris-John, M., \& Schimmel, C. J. (2005). Professional Development for Principals in the Accountability Era. Charleston, WV: Edvantia Inc.

Perez, L., Uline, C., Johnson, J., James-Ward, C., \& Basom, M. (2011). Foregrounding Fieldwork in Leadership Preparation: The Transformative Capacity of Authentic Inquiry. Educational Administration Quarterly, 47, 217-257.

http://dx.doi.org/10.1177/0011000010378614

Ravitch, D. (2010). The Death and Life of the Great American School System. New York: Basic Books.

Robinson, V. M., Lloyd, C. A., \& Rowe, K. J. (2008). The Impact of Leadership on Student Outcomes: An Analysis of the Differential Effects of Leadership Types. Educational Administration Quarterly, 44, 635-674. http://dx.doi.org/10.1177/0013161X08321509

Rodriguez-Campos, L., Rincones-Gomez, R., \& Shen, J. (2005). Secondary Principals’ Educational Attainment, Experience, and Professional Development in the USA. International Journal of Leadership in Education: Theory and Practice, 8, 309-319. http://dx.doi.org/10.1080/13603120500154182

Rosenholtz, S. J. (1989). Workplace Conditions That Affect Teacher Quality and Commitment: Implications for Teacher Induction Programs. Elementary School Journal, 89, 421-439. http://dx.doi.org/10.1086/461584

Salazar, P. S. (2007). The Professional Development Needs of Rural High School Principals: A Seven-State Study. The Rural Educator, 28, 20-27.

Schunk, D. H. (1995). Self-Efficacy and Education and Instruction. In J. E. Maddux (Ed.), Self-Efficacy, Adaptation, and Adjustment: Theory, Research, and Application (pp. 281-303). New York: Plenum Press.

Schunk, D. H. (1996). Learning Theories: An Educational Perspective (2nd ed.). Englewood Cliffs, NJ: Merrill.

Secrétariat du Conseil du Trésor du Québec (2002). Modernisation de la gestion publique: Guide sur la gestion axée sur les résultats. Québec: Gouvernement du Québec.

Smylie, M. A. (1988). The Enhancement Function of Staff Development: Organizational and Psychological Antecedents to Individual Teacher Change. American Educational Research Journal, 25, 1-30.

http://dx.doi.org/10.3102/00028312025001001

Tucker, M. S., \& Codding, J. B. (2002). The Principal Challenge. San Francisco, CA: Jossey-Bass.

Van der Westhuizen, P. C., Mosoge, M., \& Van Vuuren, H. (2004). Capacity-Building for Educational Managers in South Africa: A Case Study of the Mpumalanga Province. International Journal of Educational Development, 24, 705-719. 
Van der Westhuizen, P. C., \& Van Vuuren, H. (2007). Professionalising Principalship in South Africa. South African Journal of Education, 27, 431-446.

Warfield, C. A. (2009). A Social Network Analysis of Distributed Leadership in Schools. ProQuest Dissertations and Theses (AAI3354350).

Weindling, D., \& Dimmock, C. (2006). Sitting in the "Hot Seat”: New Headteachers in the UK. Journal of Educational Administration, 44, 326-340. http://dx.doi.org/10.1108/09578230610674949 